\title{
Municipal Utilities: An Overview Of Rate Models, Sustainability And The Effects On Affordability
}

Donald A. Forrer, Hodges University, USA

Maria Gabriela Orlando McSheehy, Hodges University, USA

Jacob Boudreau, Hodges University, USA

Elizabeth Boudreau, Hodges University, USA

Adalberto Garcia, Hodges University, USA

Maurie Kovach, Hodges University, USA

Jennifer Joseph, Hodges University, USA

Rachel Ordonio-Domingos, Hodges University, USA

\begin{abstract}
Municipalities are faced with escalating costs, harder to find resources, and increasing regulatory restrictions in an effort to maintain public utilities. To complicate this situation, communities must address a growing number of individuals who are unable to pay their utility bill. This study is a review of several water utilities in Florida to determine how typical municipal utilities approaches affordability. Factors affecting utilities such as sustainability, rate models, and regulations are examined to the present methodology for an average municipality in addressing the increasing important issue of affordability. This research is a continuation of a longitudinal study to determine how municipalities address increasing costs to maintain their utility while considering those in the community who are less fortunate and cannot continue to absorb the higher costs of water and wastewater.
\end{abstract}

\section{INTRODUCTION}

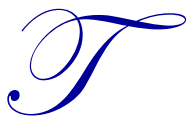

he purpose of this research is to build a body of knowledge and examine relevant literature in the areas of affordability, sustainability, conservation, and rate models in water and wastewater utilities. This effort is part of an ongoing study to examine affordability in municipal water and wastewater pricing models to determine the best way to help those who cannot afford this basic utility. The research is being conducted by a team of researchers from the MBA program at Hodges University in Naples Florida.

This research concentrates on three conflicting variables that must be considered when creating a utility rate model: 1) Sustainability, 2) conservation, and 3) affordability. As depicted in figure 1, these three often conflict when it comes to creating a viable utility rate model that makes water utilities affordable for all patrons. Water is a basic necessity, but not necessarily a basic right. Therefore, efforts to create rates concentrates on the needs of the utility. Any variance is designed to sustain a safe and plentiful supply of water for the community. Affordability for low income citizens is a concern, but not always a priority. 
Figure 1. Critical Water Issues

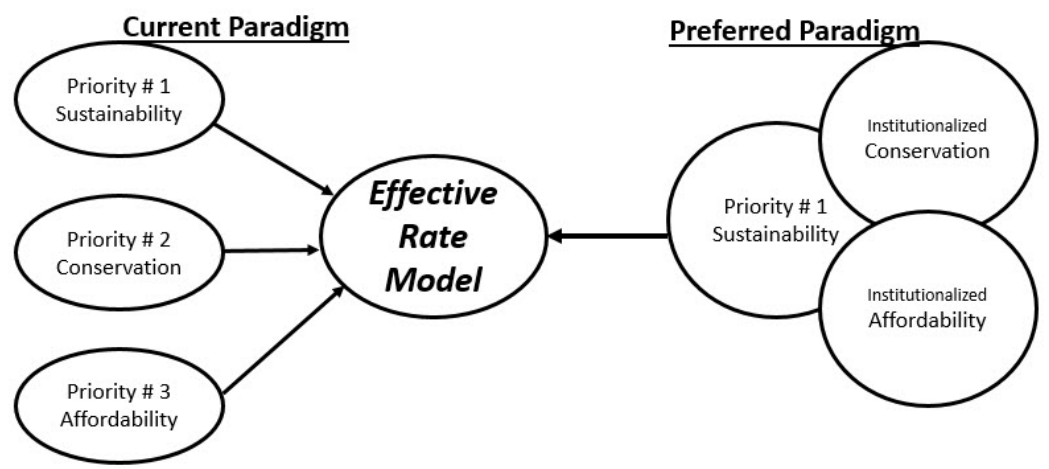

Source: Created by Authors

As noted in the conceptual diagram shown in figure 1, sustainability is a number one priority with municipal utilities with conservation and affordability included to the degree possible. When creating a strategic plan, one of the major institutional goals of the municipality should be to ensure that conservation and affordability are institutionalized in every aspect of utility operations. Conservation is normally included to the extent possible, but due to funding issues, affordability remains an issue at most utilities.

Sustainability, availability, and cost of water in America are topics that involve and affect everyone in the country, especially when the majority of changes made to water availability are man-made and not caused by nature. Water sustainability means having a continuous and clean source of water for humans and all other living creatures. Raftelis (2011) addresses the challenges that companies in the water utility industry face in order to fulfill the company's mission and vision and outlines them as follows: 1) reaching and sustaining financial sufficiency, 2) outlining and integrating the objectives of water utility companies with community sustainability goals, and 3) increase support for the utility's mission and vision by effective communication and public outreach. These goals are often in conflict with each other. This is especially true when comparing the need to sustain financial sustainability compared to other goals such as conservation and affordability.

Raftilis (2011) explains that, in addition to delivering clean water, water utility company's deal with complex financial issues such as recouping costs associated with compliance of environmental regulations and the rebuilding of underground infrastructures. In addition, research indicates that they are responsible for satisfying the needs of those in the community, which includes customers, utility employees, regulatory agencies, lending institutions, developers, suppliers, government officials, policymakers, and community leaders, who all have an equal interest in the distribution, cost, and availability of this precious resource. The Raftilis (2011) study presents a program called Effective Utility Management (EUM) which was formed for the water and wastewater utility industry as cuttingedge a management initiative addressing the difficulties in achieving financial sufficiency, community sustainability, and public communication.

Water companies are in a constant struggle to manage costs. According to Weber (2013), there are several factors involved in calculating the costs of water. Weber's study indicates that most states have regulatory restrictions that require water companies to provide water at cost $(2013, \mathrm{p} .797)$. This study relates these issues to the states of California and their Preposition 218, but it is a problem that all water distribution companies face. Operating costs fluctuate when unforeseen issues occur because they are difficult to reflect in a typical pricing model (2013, p.800). Limitations on pricing presents water distribution companies with a challenge when improvements or additional incurred costs are necessary (2013, p.829). Water companies must carefully explain their reasoning for pricing increases, additional costs and pricing regulation. Therefore, research indicates that a lack in pricing fluctuations during unusual occurrences, such as droughts, prevents the public from understanding how volatile the water supply is and does not promote consumer awareness of the difficulties balancing sustainability, conservation, and affordability (2013, p.795). 
National, state, and local constitute the three governmental levels regulating water utilities: national, state and local. The Public Service Commission is the agency that serves Florida (PSC, 2015). The PSC has the responsibility to guarantee and to promote the utilities public interest. Moreover, the PSC ensures consumers right to receive safe, reliable and affordable services. Established utility rates must cover investment in the system, but are limited on additional income and must justify each expenditure in their rate study. The Florida PSC manages municipal utilities by providing certification, rate regulation, dispute resolution, and consumer protection. The authority of the PSC is limited. The PSC regulates rates in investor owned utilities, but usually monitors, provides consumer protection and ensures consistency in public managed utilities (Florida Senate, 2015).

Florida maintains three forms of utility governance:

- Type I - A department supervised by the the City Manager.

- Type II- Utility reports to the city council or mayor.

- Type III - Utility reports to a commission or utility authority.

This research concentrates mainly on public utilities managed by a department under the control of a City manager or strong Mayor.

Counties and cities utilize a variety of Utility Rates Models to establish the proper price for water and wastewater services. Rate models are usually conducted internally or by a consulting firm and approved by the City Council or County Commission. Establishing a utility rate is a crucial element in the decision making process for any government institution. Utility models are divided into industrial, commercial, and residential segments to ensure fairness when determining price. The overall requisites of water and wastewater services are substantial. Again, this process causes conflict between sustainability, conservation, and affordability.

\section{RATE MODELS}

There are several factors that must come together when to creating utility rate models. Rate models are much more complex than just calculating how much it will cost to bring water and sewer to the people of a given geographic location. There are five important factors that need to be considered; 1) revenues to cover costs, 2) price structures that encourage conservation, 3) operational costs, 4) debt payments, and 5) administrative costs. The only place to include affordability are administrative costs which are mandated to be as low as possible. Rate tables also consider future cost increase and/or decreases.

Utility rate models utilized by water utilities play an important role in both sustainability and affordability. However, these two variables are conflicting goals when creating a rate model. Low income families are often larger in size than the national average and need more water to survive. Conservation efforts to support sustainability provides higher water bills for those who can afford it the least. Rate models must be adjusted to allow for this inefficiency.

Water and sewer requirements are vastly different and there is no way to introduce a rate model that works perfectly for every city. Rate models must be catered to each location and meet the needs of that community. The needs of the customer must also be considered. For this reason rate models are split into three different categories. These categories include; Industrial, Commercial, and Residential models. Creating rate models for each categories helps to ensure fairness in price. Rates must be fair and profits for private utility companies must be within reasonable limits set by State Governments (Mumm \& Matthews, 2004, p.67).

There are three different types of pricing models popularly used for water utility rates. These models include the; 1) Increasing Block Rate, 2) Uniform Rate, and 3) Decreasing Block Rate (Boyer, Adams, Borisova, \& Clark, 2012, p.2748). Block rates are the most popular as they allow for rate flexibility to account for conservation and changes. It is important that an approved rate model meets future predictions as these are the rates that will be charged until the next study. Utility forecasting must be as accurate as possible and plays a large role in calculating utility rates. For this reason there are several statistical models that can be employed to help forecast needs, these include; the Bivariate Model, Per Capita Requirement method, Coefficient Model and Model Misspecification. 
As noted in the chart below (table 1), there is a vast difference in utility charges depending on the municipality. Factors such as age, type of system, capital requirements and debt play a large role on cost to consumers. It is imperative that estimates for administrative costs are accurate and well managed to eliminate unnecessary elevation in the rates charged by the municipality.

Table 1. Average water charges from selected cities.

\begin{tabular}{l|c}
\hline Miami FL & $\$ 172.57$ \\
\hline San Francisco CA & $\$ 154.42$ \\
\hline Honolulu HA & $\$ 134.07$ \\
\hline Cape Coral FL & $\$ 126.97$ \\
\hline Hollywood FL & $\$ 109.21$ \\
\hline Boston MA & $\$ 102.78$ \\
\hline Houston TX & $\$ 80.81$ \\
\hline St. Petersburg FL & $\$ 80.71$ \\
\hline Borward County FL & $\$ 73.62$ \\
\hline Philadelphia PA & $\$ 73.42$ \\
\hline Jacksonville FL & $\$ 68.39$ \\
\hline Tampa FL & $\$ 62.73$ \\
\hline Dallas TX & $\$ 60.66$ \\
\hline Palm Beach County FL & $\$ 58.31$ \\
\hline Orange County FL & $\$ 55.25$ \\
\hline WASD FL & $\$ 51.11$ \\
\hline
\end{tabular}

Source: PSC. (2015, 12 09). Retrieved from http://www.psc.state.fl.us/utilities/waterwastewater/

Overall cities and other geographic locations must select rate models that meet their needs and reflect the future usage needs. Factors should include costs for providing water, administrative costs, future needs and conservation, and revenues based upon allowance. As noted earlier, the most popular structure chosen to calculate rate models is the block rate. To ensure sustainability, utility forecasting must be as accurate as possible. Because clean drinking water is a precious resource, it is expected that the costs associated with obtaining this resource will go up and the water resources themselves will to continue to decrease (Beecher, 2010).

Price, jointly with information and persuasion, can encourage efficiency, saving and conservation. Additionally, rising prices will undoubtedly lead to conservation and saving. While underpricing encourage excess usage, which can mean excessive investment capacity and also suggest inadequate financial resources. Continued underpricing may also diminish the availability of utility services. On the other hand, if the price is too high it may deter usage and can harm customers and the economy. Therefore, efficient pricing strategies link directly to how to water resources and utilities are managed.

Municipal water systems in Florida are currently examining rate structures to improve efficiency and aid in affordability. By adjusting price structures for efficiency, consumers will benefit through lower pricing (Beecher, 2010). A study by four Florida water management districts reviewed how utility rates affect families (www. swfwmd.state.fl.us). This study found the following:

- As the water price increases, use of water decreases.

- Water use varies based on the value of the property and availability of alternative water resources.

- Utilities use an inclining block rate to lower water rates is revenues allow for this flexibility. Water costs increases as use increases.

- Utilities should avoid fixed costs for utilities. Customers do not think about conservation when the charges are fixed.

- It would help to provide more pricing information on the monthly utility bill to propote conservation and affordability.

- Consumers use less water whne they have access to alternative sources such as irrigation systems. 
The following table addresses water structure and price of selected cities in Florida.

Table 2. Residential rate structure for selected cities.

\begin{tabular}{|c|c|c|c|c|}
\hline Location & Water Base Charge & Consumption & $\begin{array}{c}\text { Wastewater Base } \\
\text { Charge }\end{array}$ & Consumption \\
\hline Auburndale & $\$ 9.53$ & $\begin{array}{l}\text { Range from } \$ 1.75 \\
\text { per } 1,000 \text { gal to } \\
\$ 3.46(1,000 \text { gal }) 5 \\
\text { blocks }\end{array}$ & $\begin{array}{l}\$ 33.85 \text { per Month } \\
\text { (Flat Charge) }\end{array}$ & \\
\hline Bartow & $\$ 9.73$ & $\begin{array}{l}\text { Range from } \$ 2.25 \\
\text { per } 1,000 \text { gal to } \\
\$ 4.16(1,000 \text { gal }) 3 \\
\text { blocks }\end{array}$ & $\$ 21.32$ Base Charge & $\begin{array}{l}\text { Range from } \$ 1.78 \\
\text { per } 1,000 \text { gal to } \$ 10 \\
\text { per } 1,000 \text { gal }\end{array}$ \\
\hline Citrix county & $\$ 12.31$ & $\begin{array}{l}\text { Range from } \$ 1.25 \\
\text { per } 1,000 \text { gal to } \\
\$ 3.67(1,000 \text { gal }) 5 \\
\text { blocks }\end{array}$ & $\begin{array}{l}\$ 11.97 \text { based plus } \\
\text { consumption to a } \\
\text { cap of } 6,000 \text { gallons }\end{array}$ & \\
\hline Clearwater & $\$ 17.80$ & $\begin{array}{l}\text { Range from } \$ 7.21 \\
\text { per } 1,000 \text { gal to } \\
\$ 9.09(1,000 \text { gal }) 2 \\
\text { blocks }\end{array}$ & $\$ 24.51$ Base Charge & $\begin{array}{l}\text { Range } \$ 8.17 \text { per } \\
1,000 \text { gal }\end{array}$ \\
\hline Daytona & $\$ 14.12$ & $\begin{array}{l}\text { Uniform Rates of } \\
\$ 4.65 \text { per } 1,000 \text { gal }\end{array}$ & $\$ 11.72$ & $\begin{array}{l}\text { Uniform rate of } 90 \% \\
\text { of water charges }\end{array}$ \\
\hline Ft. Myer & $\$ 9.55$ & $\begin{array}{l}\text { Range from } \$ 4.67 \\
\text { per } 1,000 \text { gal to } \\
\$ 15.37(1,000 \text { gal }) 4 \\
\text { blocks }\end{array}$ & $\$ 16.14$ & $\begin{array}{l}\text { Range from } \$ 11.40 \\
\text { per } 1,000 \text { gal to } \\
\$ 13.89 \text { to } 10,000 \\
\text { gals (Maximum) }\end{array}$ \\
\hline Orlando & $\begin{array}{l}\text { Purchase water from } \\
\text { Orlando Utility } \\
\text { Commission }\end{array}$ & & $\$ 17.84$ & $\begin{array}{l}\text { Range from } \$ 4.31 \\
\text { per } 1,000 \text { gal to cap } \\
\text { of } \$ 14 \text { per } 1,000 \text { gals }\end{array}$ \\
\hline
\end{tabular}

Source: PSC. (2015, 12 09). Retrieved from http://www.psc.state.fl.us/utilities/waterwasteeater/

As noted in the chart above (Table 2), even in the same state, there are a wide variance in charges for water service. A typical water bill will have a commodity and capacity charge that customers pay regardless of usage. Customers are charged a service fee for the fact that the plant is available (Capacity) and the pipes are available at the residence (commodity) even if there is never a gallon of water used. Customers are then charges a fee per 1,000 gallons of water utilized in a given period. Wastewater is charged based on water usage since there is no viable way to measure wastewater usage. The fee for wastewater is typically higher that the fee for water due to the cost differences in operating a water plant versus a wastewater plant.

\section{SUSTAINABILITY/CONSERVATION}

As water becomes more and more scarce, sustainability is a concern at all levels of government. A recent article in the USA Today (December 11, 2015), provided an overview of water wells nationwide that are declining. This is especially a problem in several midwestern states and effects two-thirds of the wells in the United States. Facts cited in this article included a considerable amount of depleted groundwater from US aquifers. Some areas have experienced more than 100 feet over ten years. The issue is serious and water officials are working to address the situation.

Research indicates that our clean water is at risk and that more and more US citizens are having problems paying for service. There are several reasons for issues facing the water industry including waste, accidents, apathy, aging systems, and natural causes. A 2010 study by ITT Corporation found that across the country there were approximately 650 water mains break daily due to aging infrastructure. Additionally, over $\$ 2.5$ billion worth of 
water is lost yearly for various reasons including spillage, leakage, and neglect. The biggest issue is that approximately $69 \%$ of American citizens and $72 \%$ of surveyed businesses largely take the availability of clean water for granted. Only one out of four citizens indicate they are "very concerned" about condition of water infrastructure and only $29 \%$ believe that aging water infrastructure is near a crisis level. However, $80 \%$ of those surveyed indicate that utility infrastructure should be reformed. The survey indicates a lack of awareness when it comes to water and wastewater infrastructure and sustainability issues (Value of Water Survey, 2010).

Water is a commodity that the world needs for survival and sustainability must be the target of all municipalities. Conservation is a major initiative to maintain a viable water supply and it is built into most rate models for this reason. This paper concentrates on the State of Florida. We have abundant amounts of sun, sand, and water (Marella, 2010). It is hard to believe that a state with over 54 inches of rain per year and such plentiful water sources can be perpetually in need of more water. Unfortunately, even though water is a renewable resource, the supply is limited. Sources of water that have taken tens of thousands of years to accumulate are being used in just a matter of decades (James \& Reilly, 2015). Additionally, with constant growth, the demands on water sources will surpass Florida resource capabilities is the state does not engage in careful planning.

Historically, Florida has shown a rapid rate of population growth. U.S. Census Bureau data reflects that Florida is third most populous state with a total of 19.89 million people. Florida's total use of water in 2010 was estimated to be about 14,988 million gallons per day (Marella, 2010). According to the 2014 Integrated Report from the Florida Department of Environmental Protection, ninety percent of Florida's population depends on ground water resources such as springs and aquifers for their drinking water. Concerns about water resources have increased in the last years basically, as the result of human activity like population expansion, pollution, the effects of climate change and variations in natural conditions.

There are a lot of issues that can be addressed in the area of sustainability. In the state of Florida, once a water use permit is issued, the only cost for withdrawing water from the selected aquifer, river, or lake is the price of the pump and the cost of the electricity that is required to remove the water from the source. There is no established water use fee and there is a public call for this to change. Swihart (2011) proposes that Florida establish the application of water use fee to be paid by utility companies. In theory, the creation of a water market could reduce the damage done by over-pumping and a modest water fee would make it easier to manage the problems with Florida's water supply. The Regulated Riparian Model Water Code adopted by the American Society of Civil Engineers (ASCE) expresses the importance of the implementation of a water use fee:

Without requiring fees for the value of the water used, one cannot really hope to achieve real efficiency in the use of water and therefore of ensuring sustainable development [....] In any event, it is important that water users cease to consider water a "free good" if we are to achieve a high measure of efficiency in the use of water and to see the application of water to hits higher valued uses (ASCE, 2004).

This call for a fee is not unprecedented. Other natural resources have imposed use fees as in the case of mining of valuable minerals and barrels of oil extracted from oilfields. Additionally, other states have instituted the water use fee system; 1) New Jersey charges a penny per thousand gallons for water delivered to consumers by public water suppliers, 2) Kansas charges three cents per thousand gallons as a Water Protection Fee, 3) Iowa charges fees not to exceed $\$ 500,000$ to cover the cost of application review, permit issuing, and ensuring compliance, and 4) Minnesota charges $\$ 8.00$ per million gallons if above 500 million gallons per year are used.

Florida has considered the application of water use fees but has never established any fees. Swihart (2011) states that the establishment of a water use fee would be simple and much easier to manage than other states. There are a few different ways that the water use fee could be structured:

1. A fee on permitted withdrawal capacity

2. Different fees on different types of water use

3. Different fees for different regions or hydrologic circumstances

4. Volumetric fees for end users 
These fees will promote efficiency in water management and assist with sustainability efforts. Districts such as the SFWMD which use large amounts of water would have a greater incentive to conserve water. Municipalities must plan for sustainability to ensure safe water for the future. One of the methods utilized to ensure sustainability is utility rate models.

\section{AFFORDABILITY}

According to Baird (2010), customers feel as if they are being taken advantage of by a complex water system. Funding for municipal water is convoluted with the needs of the government, citizen, municipality, environmentalist, and others to the point that it is difficult to determine what is included in the typical utility bill. The American Water Works Association (AWWA) encourages municipalities to disclose full cost pricing to customers. However, few understand what is included and how it pertains to them as consumers. Baird (2010) defines full cost pricing as everything included in the rate model to include asset management and replacement costs. The cost of water must include sustainability for the future and it is difficult to explain this to the typical customer. The US Environmental Protection Agency (USEPA) outlines steps necessary for sustainability and infrastructure management, but does not adequately address affordability.

A typical water utility bill is increasing and not everyone is able to afford these cost increases. A study by Whitcomb, 2005 references individuals and families who reside in single-family homes. Three specific issues are discussed in this study. The first issue was to acquire knowledge about the different methods of pricing. Research indicates that in the state of Florida utility companies normally use increasing block rate models for conservation. The second issue addressed wealth and price sensitivity. The authors attempt to answer questions similar to "as water prices increase do the wealthy customers lower their water usage?" The study indicates that while utility affordability programs are very beneficial to low-income families it appears that as utility pricing increases only the lower income families are practicing water conservation. The third issue determined that utility sustainability was most effective if all consumers participated in water conservation. Whitcomb (2005) evaluated water and sewage prices to provide information for organizations to create effective affordability programs.

The Census Bureau (2015) reflects that the median household income in the state of Florida is $\$ 47,212$. The state of Florida household income is lower than the United States average, which is $\$ 53,482$ (Census Bureau, 2015). As of $2014,16.5 \%$ of Florida residents were considered to be living in poverty. The 2015 poverty guidelines have determined that a household consisting of four (4) individuals is considered to be in poverty if the total household income is equal to or less than $\$ 24,250$ a year (Poverty Guidelines, 2015). This data is merely contingent to the continental US; the poverty guidelines for Alaska and Hawaii will vary. The chart below illustrates how Florida compares with the United States. Lee County Florida is also illustrated. 
Figure 2. Income vs Poverty Level for selected areas.

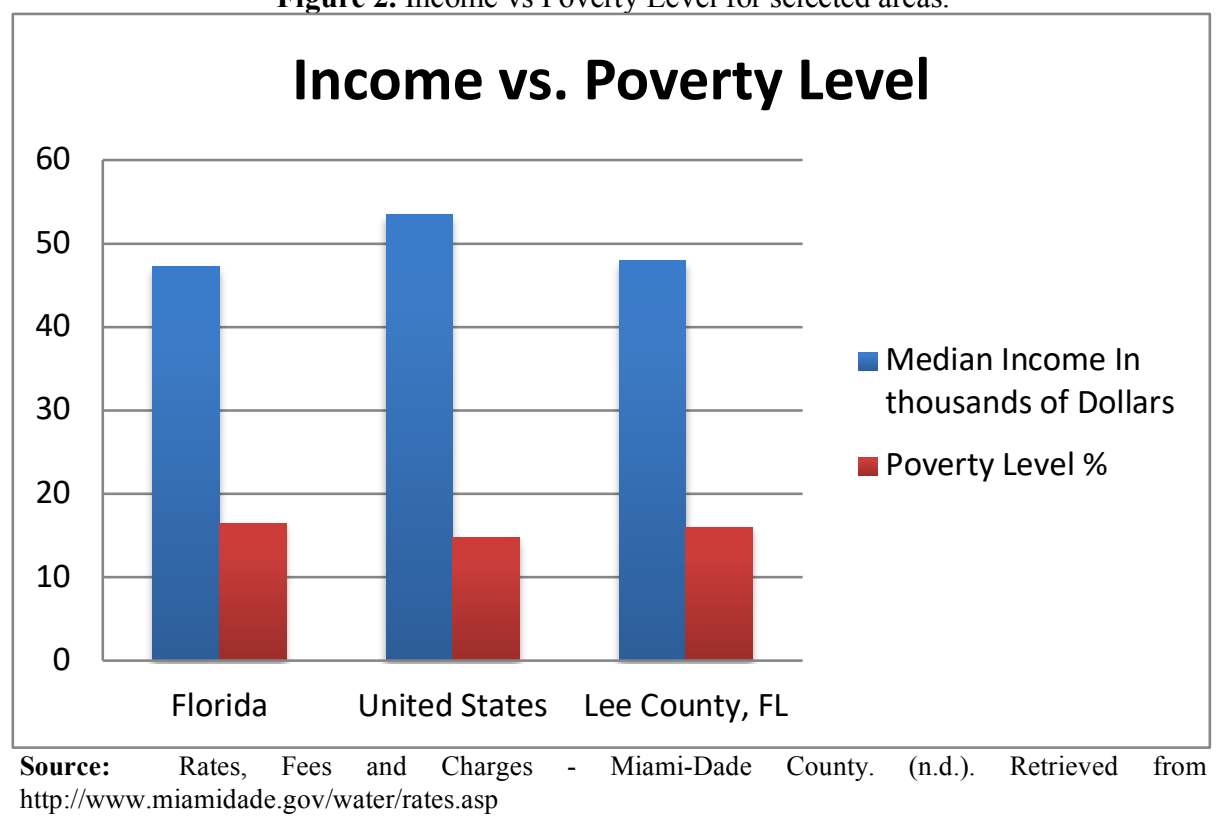

In the United State of America the average water and sewer bill differs depending on the location. For instance, the average monthly water bill in Atlanta, GA is $\$ 172.57$ which is more than in San Francisco, CA where the average water and sewer bill is $\$ 154.42$ (Combined water, 2015). Utility costs in the state of Florida fluctuates greatly. In Cape Coral, FL the average monthly water and sewer bill is $\$ 126.87$, whereas in Orange County, FL the average bill is $\$ 55.25$ (Combined water, 2015).

Monthly residential water charges are a combination of the standard meter changed plus the water usage. For example, effective October 1, 2015 a meter size of 5/8" (Standard meter size) will have a base charge of $\$ 3.20$ in additional to the amount of water used (Rate and Fees, 2015). The monthly water and sewer bills mentioned above are based on the average residential water consumption, 6,750 gallons per month, which is roughly 9ccf (Rate and Fees, 2015). Figure 3 demonstrates the differences in utility charges is four major cities.

Figure 3. Utility bill vs income vs. poverty level for selected cities.

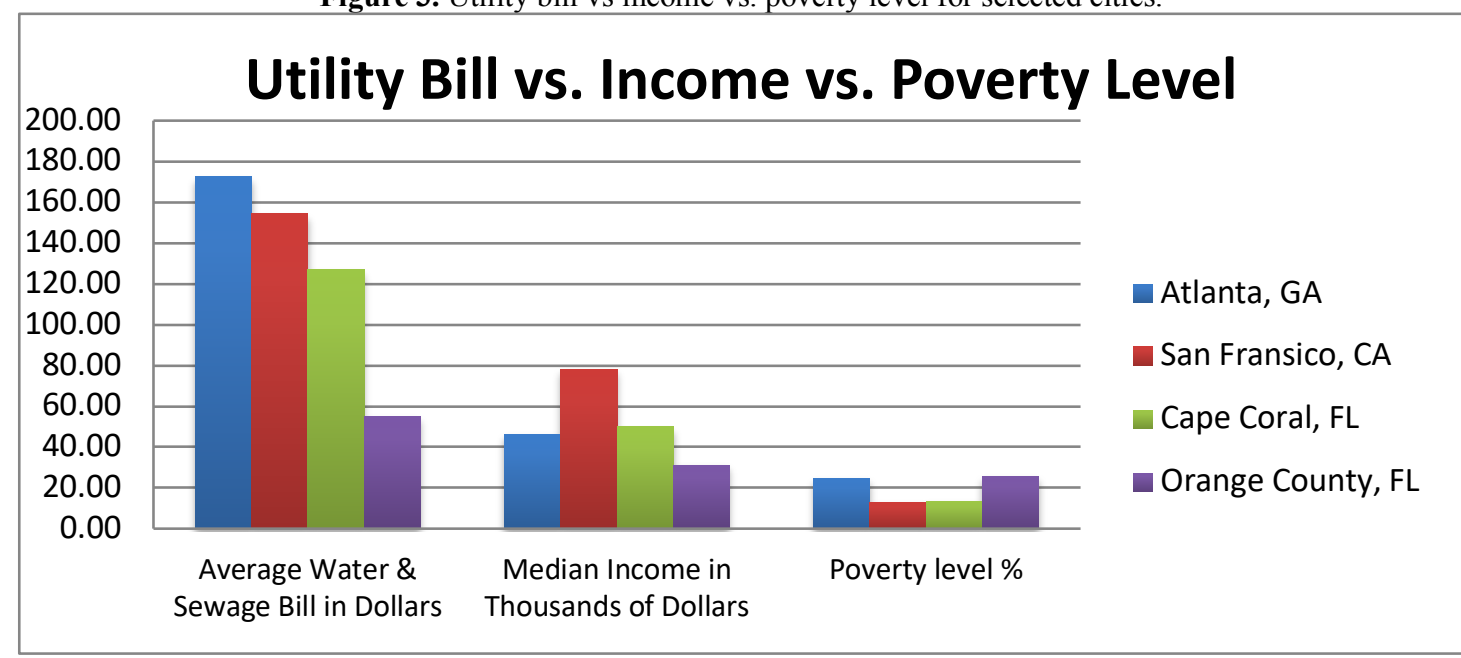

Source: Rates, Fees and Charges - Miami-Dade County. (n.d.). Retrieved from http://www.miamidade.gov/water/rates.asp 
In areas such as Belle Glade Florida households are not charged per water usage due to the high percentage of individuals below the poverty line. In Belle Glade, the water and sewer charges are billed as a flat rate to all consumers. The flat rate water and sewer change in this area of Florida is $\$ 62.50$ per month (Barnett, 2007). All households in this area are required to pay the flat rate regardless of water usage. Though the average monthly cost for water and sewer may seem high, on average only $1.1 \%$ of household income is spent on water in the United States (Darilek, n.d.).

In 2006, the USEPA created the following principles to aid with affordability; 1) water rates should not worsen the affordability problem, 2) municipalities should identify customers in need of assistance, 3) sources for subsidies should be identified by municipalities, and 4) a safety net will be created to stop lower income families from losing the utility (Baird, 2010).

\section{CONCLUSION}

There is a significant difference among the different Florida Cities and Counties in terms of environmental and urbanization, that is why it is crucial that the authorities develop a rate model that considers all the elements that impact the costs of water and wastewater and the necessity of it population. It is difficult, if not impossible, to create a unique model that addresses all circumstances. However, a rate model should be as accurate as possible. This will allow flexibility so that efficiency and conservation can be accomplished by each municipality. Efficient and understandable prices will lead to more efficient water usage and funds to make water and wastewater affordable.

As noted earlier, this paper was written as a literature and fact fining paper to be included in a body of knowledge work to create a utility rate model that includes methodology for helping those who cannot afford to pay the increasing costs of water, wastewater, and irrigation. The conceptual diagram (figure 4) displayed below will form the nucleus of this research.

Figure 4. Proposed affordability pricing model.

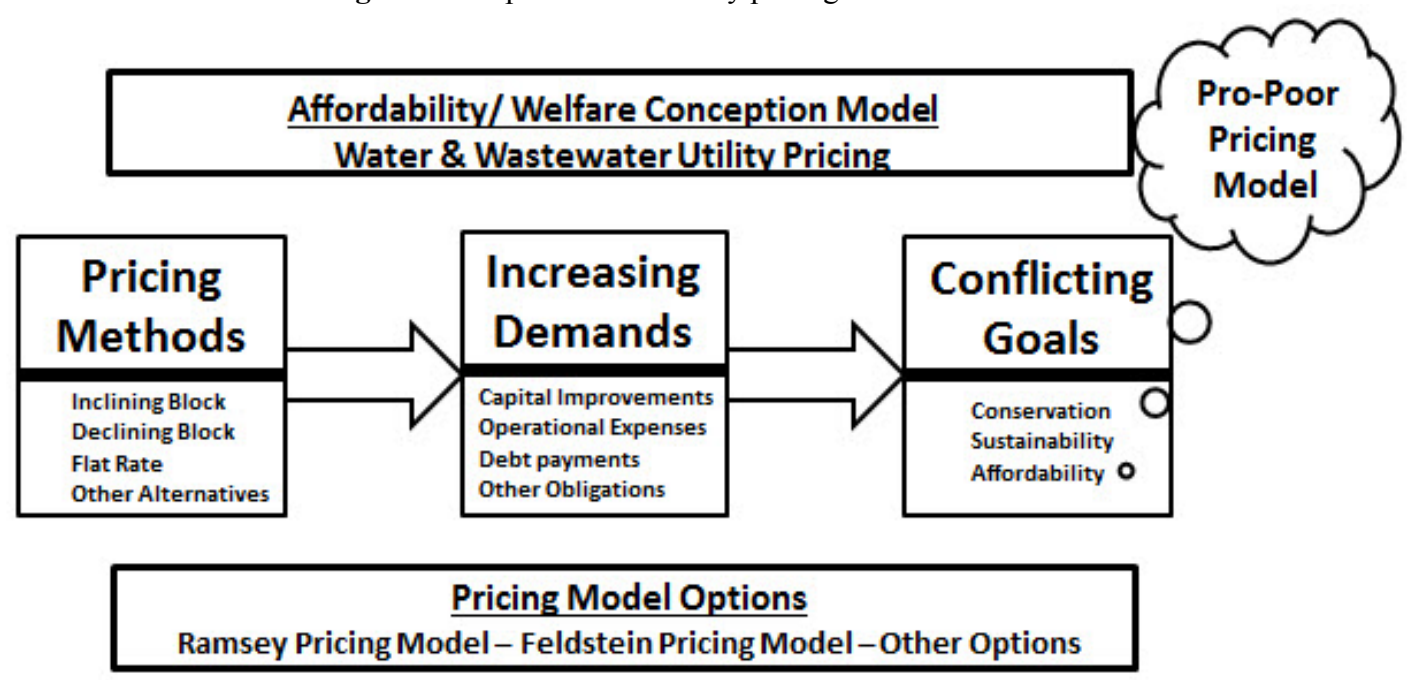

Source: Forrer, D. et.al. (June 2016). The effects of water utility pricing on low income consumers. Presented at the International Academics Conference, The Clute Institute, London England.

There is an urgent need for policy makers, water management districts, and water utility companies to seriously develop and implement decisions and strategies such as water use fees and utility rate models that will address the current water supply problems and sustainable water conservation issues in the state of Florida. There is a significant difference among the different cities and counties of Florida in terms of population numbers and expanding urbanization, which is why it is crucial that the authorities develop water use fees and rate models that 
take into account all of the elements that will promote the future sustainability of Florida's water resources. The future depends on municipalities finding a way to satisfy both sustainability and affordability. The key is a utility rate model that addresses both issues.

Baird (2010), points out that "The Clean Water Act" requires USEPA to ensure affordability of water utilities. To accomplish this, the USEPA determined that no more than $2.5 \%$ of household income is the maximum that should be paid for water and wastewater utilities. While this is effective, the arbitrary percentage does not consider the ability of lower income groups to afford even this level of costs. However, a study of eighty-eight Colorado rural communities demonstrate that the majority (60 municipalities) fell at $1 \%$ or below with only one community recorded at a level above 2.5\%. As noted in the Baird (2010) article, there are numerous elements to water sustainability and affordability, but it has yet to be determined who is going to pay the bill.

\section{REFERENCES}

American Society of Civil Engineers (ASCE). (2004). Regulated Riparian Model Water Code, Section 4R-1-08, ASCE/ESRI 40003, ASCE, Reston, VA p 48-49

Audubon. (2015). Water for the environment. Retrieved from http://fl.audubon.org/water-environment.

Barnett, C. (2007, March 1). Water, Water. Retrieved from http://www.floridatrend.com/article/10132/water-water

Baird, G. (2010). Water affordability: Who's going to pick up the check? American Water Works Association Journal.

Beecher, J. (2009) Private water and economic regulation in the United States, In: Bausch, A.and Schwenker, B.(eds) Handbook Utility Management, 779 - 801 (Berlin: Springer)

Beecher, J. (2010). Water pricing primer for the great lakes region. Michigan State University. Retrieved from https://myhugo.blackboard.com/bbcswebdav/pid-3212657-dt-content-rid10821413_1/courses/MBA_PROJECT_SHELL/GL-Water-Primer_MSU.pdf

Boyer, C. N., Adams, D. C., Borisova, T., \& Clark, C. D. (2012). Factors driving water utility rate structure choice: Evidence from four southern U.S. states. Water Resources Management, 26(10), 2747-2760.

Broward County (2011). Water Services. Retrieved from http://www.broward.org/WaterServices/Documents/RetailRateStudy2011.pdf.

Carter, L.J., (2013). The Florida experience: Land and water policy in a growth state. Retrieved From http://reader.eblib.com.hodges.idm.oclc.org/(S(dr1vubstyjcooc4gz55sq3cf) $/$ Reader.aspx?p=1569800\&o=61\&u=QIQt VRjQ\%2f91zyCnSueeeug\%3d\%3d\&t=1451356575\&h=CA6B3F42A2CA7D029B842F9767C2545CDE93974E\&s=40 908465\&ut=137\&pg=1\&r=img\&c=-1\&pat=n\&cms=-1\&sd=2

Conner, R. (2014). Lakeland Water Utilities. Water \& Sewer Utility Rate Study FY 2013 - 2014. Retrieved from https://www.lakelandgov.net/Portals/Water/2014REPORT\%20-\%20FINAL.pdf

Combined water and sewer bill Florida municipalities and major US cities for the average residential customer. (n.d.). Retrieved from https://www.miamidade.gov/water/library/fees/rate-comparison.pdf

Darilek, P. (n.d.). A closer look: Water and power. Retrieved from http://thewaterproject.org/resources/twp-handouts.pdf

Florida Senate. (2015, 12 6). Retrieved from http://www.flsenate.gov/Laws/Statutes/2015/Chapter367.

Florida Department of Agriculture and Consumer Services (FDACS)., (2015). Florida

Agriculture overview and statistics. Retrieved from http://www.freshfromflorida.com/Divisions-Offices/Marketing-andDevelopment/Education/For-Researchers/Florida-Agriculture-Overview-and-Statistics

Forrer, D. and Kessler P. (2008). A utility rate model for water and wastewater: Concept and issues. Retrieved from http://www.professorforrer.com/Research_Data/Papers/ICPA2008_UtilityRateModel_Forrer-Kessler.pdf.

Forrer, D. et.al. (June 2016). The effects of water utility pricing on low income consumers. Presented at the International Academics Conference, The Clute Institute, London England.

Green Facts (n.d.). Water resources. Retrieved from http://www.greenfacts.org/en/water-resources/

Holburn, G. \& Bergh, R. (2006) Consumer capture of regulatory institutions: The creation of public utility consumer advocates in the United States, Public Choice, 126(1), pp.45-73.

Holt, L., Jamison, M., Kury, T., Phillips, M., Jarrett, L., Jones, P., Miller, C., Seatcy, J., Taylor, N., Chaser, D., Nelson, J., Sonne \& Vieira, R (2015). Florida multifamily efficiency opportunity study. University of Florida Public Utility Research Center. Retrieved from: http://www.freshfromflorida.com/content/download/60388/1263496/MFEOpportunities_FinalReport_1-9-15.pdf.

James, I., \& Reilly, S., (December 10, 2015). Pumped beyond limits, many U.S. aquifers in decline. Retrieved from http://www.desertsun.com/story/news/environment/2015/12/10/pumped-beyond-limits-many-us-aquifersdecline/76570380/

Koch-Rose, M., Mitsova-Boneva, D., \& Root, T., (2011). Florida water management and adaptation in the face of climate change; a white paper on climate change and Florida's water resources. Retrieved from http://floridaclimate.org/docs/water_managment.pdf 
Marella, R.L., (2010), Water withdrawals, use, and trends in Florida, 2010: U.S. Geological Survey Scientific Investigations Report. Retrieved from http://pubs.usgs.gov/sir/2014/5088/pdf/sir2014-5088.pdf

Marin, P. (2009) Public-private partnerships for urban water utilities: A review of experiences in developing countries (Washington DC: World Bank Publications).

Mumm, J., \& Matthews, P. (2004). Adapting GASB 34 for water utility rate-making. American Water Works Association.Journal, 96(1), 65.

Our Water is Running Out. (December 11, 2015). USA Today. Section B.PSC. (2015, 12 09). Retrieved from http://www.psc.state.fl.us/utilities/waterwastewater/

Raftelis, G.A. (2011). Balancing financial sufficiency and community sustainability. Journal American Water Works Association, 103(9), 56-59.

Rates, Fees and Charges - Miami-Dade County. (n.d.). Retrieved from http://www.miamidade.gov/water/rates.asp

Southwest Florida Water Management District (n.d.). Water Rates: Conserving Water and Protecting Revenues. Retrieved from https://www.swfwmd.state.fl.us/conservation/waterrates/

Southwest Florida Water Management District (n.d.). Water Rates: Conserving Water and Protecting Revenues. Retrieved from https://www.swfwmd.state.fl.us/conservation/waterrates/

Swihart, T., (2011). Florida's water: a fragile resource in a vulnerable state. Retrieved from http://reader.eblib.com.hodges.idm.oclc.org/(S(wwcopuglotirywgfddgp1qkq))/Reader.aspx?p=982533\&o=61\&u=QIQt VRjQ\%2f91zyCnSueeeug\%3d\%3d\&t=1451352337\&h=74461505EADA67DE36340709DACD1AFF7A8FFC88\&s=4 0908133\&ut=137\&pg=1\&r=img\&c=-1\&pat=n\&cms=-1\&sd=2

The Constitution of the United States. (n.d.). Retrieved December 11, 2015, from http://www.usconstitution.net/const.pdf

United States Census Bureau. (2015). Retrieved from http://www.census.gov/quickfacts/table/IPE120214/1210275,1304000,0667000,1251825

USGS (n.d.) The USGS Water Science School. Retrieved from http://water.usgs.gov/edu/gwdepletion.html

Value of Water Survey. (2010). ITT Corporation.

Water and Sewer (2015). Rates, fees and Charges. Retrieved from http://www.miamidade.gov/water/rates.asp\#2

Weber, G. S. (2013). A new water accounting. Ecology Law Quarterly, 40(4), 795-831.

Whitcomb, John B. 2005. Florida water rates evaluation of single-family homes. Retrieved from: http://www.swfwmd.state.fl.us/documents/reports/water_rate_report.pdf. 
NOTES 